Moos, Lejf (2013). School Leadership in a Contradictory World. Revista de Investigación Educativa, 31 (1), 15-29. http://dx.doi.org/10.6018/rie.31.1.162511

\title{
SCHOOL LEADERSHIP IN A CONTRADICTORY WORLD
}

\author{
Lejf Moos \\ Department of Education (DPU) Aarhus University, Copenhagen, Denmark. \\ President of The European Educational Research Association (EERA) \\ moos@dpu.dk
}

\begin{abstract}
The article captures important trends and tendencies in public governance and thus in conditions for school leadership. The general movement towards Globalization influences the core trends in national policies and in public governance. But international discourses and practices are formed in national or regional contexts of culture, practice and politics. The author is part of a Nordic context and therefore he observes governance and leadership from this point. But it is possible to translate the analyses to other contexts as well. An analyse of some of the effects of the meetings of transnational influences with national values and practises are discussed in the case of Danish education and school leadership. School leaders are left with a number of dilemmas between traditional, welfare state values and neo-liberal values. They have to find locally satisfying balances between academic proficiencies and competences of curiosity and deliberation.
\end{abstract}

Keywords: school leadership, neo-liberal globalization, local values, accountability, innovation.

\section{EL LIDERAGO DE LA ESCUELA EN UN MUNDO CONTRADICTORIO}

\section{RESUMEN}

En este artículo se aborda las tendencias más destacadas en la gobernanza pública y su repercusión en el liderazgo de la escuela. El movimiento general hacia la globalización influye

\section{Correspondencia:}

Lejf Moos, Department of Education (DPU) Aarhus University, Copenhagen, Denmark is the President of The European Educational Research Association, EERA. moos@dpu.dk 
en las tendencias centrales de las políticas nacionales y en la goberanza pública. Sin embargo, las prácticas y discursos internacionales se forman en contextos nacionales o regionales de la cultura, práctica escolar y política. El autor pertenece al contexto nórdico y por tanto analiza la gobernanza y el liderazgo desde ese punto de vista, aunque es posible trasladar dicho análisis a otros contextos. En este trabajo se analizan algunos de los efectos de la fusión de influencias transnacionales con valores y prácticas nacionales en el caso de la educación danesa y el liderazgo escolar. Los líderes escolares se encuentran ante una serie de dilemas entre los valores tradicionales, el estado del bienestar y los valores neoliberales. Como consecuencia, tienen que encontrar un equilibrio entre el rendimiento académico satisfactorio y las competencias de curiosidad y deliberación.

Palabras clave: Liderazgo escolar, globalización neoliberal, valores locales, responsabilidad, innovación.

\section{ILLUSTRATING DIFFERENT CONTEXTS: DIVERSE DISCOURSES AND PRACTICES}

When looking at Globalization and transnational influences one often gets the impression that all societies are equally affected by those trends. This is not the case, because transnational influences meet a local sounding board and are adjusted and filtered to fit local conditions, traditions, values and practices. In order to illustrate this argument we shall introduce a short description of different discourses and values: A Nordic and an UK and US variant of societies and educational discourses (Moos, 2013b).

Over the past centuries different societies were build on the basis of different values and practices. This is the case with the Nordic countries (Denmark, Finland, Iceland, Norway and Sweden) and the UK and US sphere. In short, the Nordic countries are by tradition more egalitarian than the UK and the US. This historical-sociological fact constitutes a basis for the development of local practices, relations and values. In the UK and the US it is part of the traditional understanding and discourse to accept steeper hierarchies and stronger, more direct leadership than in the Nordic systems, where flatter structures and more collegial relations are expected.

Political differences contribute to this trend. The UK and the US democracies are more liberal with a deep belief in individual choice and competition, while the Nordic countries have a more social democratic history with as deep a belief in community and local as well as national collaboration. The Nordic welfare state is described as based on belief in a strong state, in a particular set of labour market institutions and a high rate of investment in human capital (Andersen et al., 2007). This is (only a fraction of) the background that forms the prism through which new impulses and expectations are seen and understood.

When analyses build on sociological theories (Bourdieu, 1977; Bourdieu, 1990; Bourdieu \& Passeron, 1977), it is reasonable to take the social conditions in which education is placed as the point of departure for educational analysis. Therefore, a few figures from the UK and the US as well as the Nordic countries are included.

Differences in equality/inequality and distribution of income (the GINI index, after taxes and transfers) show that on a scale from 0 (total equality) to 100 (total inequality), 
the UK and the US score around 36-40. The Nordic countries score 22-29 (OECD, 2012, August, 30). This means that the gulf between poor and rich is much wider in the UK and the US than in the Nordic countries. Over a period of 10-15 years, unfortunately the gap is widening in all these countries. The difference between the Nordic countries and the US and the UK however, remains the same.

Similar results are seen in a UN report. In the Nordic countries the richest 20 per cent of the population is approximately four times richer then the poorest 20 per cent, while the richest 20 per cent of the population is approximately eight times richer then the poorest 20 per cent in the UK and the US (UN 2006 in Wilkinson \& Pickett, 2009, p. 17).

Health and social problems are closely related to social inequality, not to average incomes, as might be expected. The divide produces health and social problems (UN 2006 in Wilkinson \& Pickett, 2009, p. 20).

Another effect of social inequality is the level of people who believe that most people can be trusted. The level is 60-70 per cent in the Nordic countries and only 30-35 per cent in the UK and the US (Arbor 2005 in Wilkinson \& Pickett, 2009, p. 52). A very similar picture arises, when we look at relations between social inequality and women's status (Wilkinson \& Pickett, 2009, p. 60).

These figures point to analyses and discussions of social class. Social class is a concept in social sciences and political theory, centred on models of social stratification in which people are grouped into a set of hierarchical social categories. A social class encompasses people with the same social, economic or educational status. Marxist theory tells us that class relations build on relations to means of production. So class is a sociological signifier for the distribution of wealth and thus predominantly an economic category. However, some sociologists argue that 'Class is no longer an important basis of social identity and interests [...] Perhaps of more importance is the noticeable effect of education on class identity and perceptions' (Evans, 1992, p. 251).

When it comes to the perception of social position and belonging, it is interesting to combine Evans' argument with analyses of free - state funded - access to education. The public versus private proportions of funding for education differ. For example, Norway has only 1.8 per cent and Denmark 7.8 per cent private funding for education, while the UK has 30.5 per cent (Eurydice, 2012, p. 93), which means that it is a greater challenge for families to find funding for education in the UK (and the US) than in the Nordic countries. It is fair to argue that there is a clearer social divide - and perception of social positioning in the UK and the US than in the Nordic countries. The gap between poor and rich is larger in the UK and the US, and this coincides with the perception of trust: half as many people can be trusted in the UK and the US as in the Nordic countries. There used to be a steeper hierarchy in the UK, though.

This is also evident from the traditional institutional structures. In the UK there were eight layers in schools: school leader, deputy, assisting deputy, department leader, deputy department leader, assistant deputy department leader, teacher, assisting teacher. The Nordic countries usually had a flat structure with three layers: school leader, deputy, teacher.

Nordic social democracies focus on the welfare state thinking of social rights and equality (Andersen et al. 2007) within a cohesive community. A strong state that is able 
and willing to redistribute some of the wealth is necessary. Often the idea of social democracy is combined with ideas of participation. Citizens are supposed to participate in discussing and deciding on matters of common interest.

Democratic thinking is different in the UK and the US. Most well-known is liberal democracy that built on the premise that the purpose of society is to benefit the individual in her/his development. In these societies the role of the state is to ensure that institutions and communities do not obstruct the liberty of individuals (Louis 2003).

\section{Educational legacy}

Schools are societal and cultural institutions with the core purpose of building an authoritative and competent next generation. School leaders are supposed to manage schools and ensure optimal conditions for the core function of a school (student learning), the core mediator of learning (teachers' education) and the core context for education and learning (the school organisation) (Day \& Leithwood, 2007b; Moos, 2011).

As this is the basis for our analyses, we can describe two different ways of thinking education. One is recognizable in Nordic educational history and values, the progressive education (Blossing et al., 2013 ). Building on Dewey (Dewey, 1901; Dewey, 1916) progressive education reconciles both individualism and community by stimulating the child to develop in her/his own way and learn from personal experience, and concurrently organise the learning processes so that cooperation and social interdependence are encouraged. This is an educational ideology that is well-suited for a school system that aims to embrace all societal groups and a wide variety of students. Another trend is effectiveness education. Three elements in the American Post World War II curriculum tradition: first, the idea about curriculum objectives, originating from, among others, Franklin Bobbitt (1924); second, the conception of learning outcomes as an entity that can be measured objectively; and third, the technological means-end model formulated by Ralph Tyler (1949).

These three elements serve as important tools in the neo-liberal governance systems that have been developing since the 1990s, both in the US and in the rest of the world. They are very important foundations for the emergence of global competition in education-based comparisons, transnational indicators and political demand of accountability, measured on outcomes (Blossing et al., 2013 ).

A very rough summary of different educational visions in the US and the Nordic systems in the three decades following the Second World War should include the following: The US developed scientific curriculum thinking with focus on national/ scientific goals and measurable outcomes. There is an inclination for Taylorism, i.e. scientific management (Taylor, 1911) in education, building on the idea that by splitting up all processes, one may be able to manage them to perfection. These ideas often result in detailed aims, standards and quality indicators and manualisation of practice by prescribing it step by step. In the Nordic education systems there was a strong belief in democratic participation, student activity and comprehensive schooling.

Tendencies in society and education and a general image of NPM can be described in this way (Moos, 2013a): 


\begin{tabular}{|c|c|c|c|}
\hline \multicolumn{4}{|c|}{ Strong tendencies in discourses and public management } \\
\hline & $\begin{array}{l}\text { Nordic tendencies } \\
\text { post-WWII to } 1980\end{array}$ & $\begin{array}{l}\text { UK/US tendencies } \\
\text { post-WWII to } 1980\end{array}$ & $\begin{array}{c}\text { New Public } \\
\text { Management 1980- }\end{array}$ \\
\hline 1 & $\begin{array}{l}\text { The Nordic welfare state } \\
\text { believes in a strong state } \\
\text { and strong local commu- } \\
\text { nities. }\end{array}$ & $\begin{array}{l}\text { The UK/US liberal state } \\
\text { believes in a strong mar- } \\
\text { ket and a weak state. }\end{array}$ & $\begin{array}{l}\text { Economic incentives } \\
\text { to maximise personal } \\
\text { gains: marketplace, eco- } \\
\text { nomic theories. }\end{array}$ \\
\hline 2 & $\begin{array}{l}\text { A strong trend is the } \\
\text { belief in comprehensive } \\
\text { education and in educa- } \\
\text { tion for participation in a } \\
\text { democracy, equality and } \\
\text { comprehensive Bildung } \\
\text { (in order to educate hu- } \\
\text { man beings). }\end{array}$ & $\begin{array}{l}\text { Strong trends are scien- } \\
\text { tific curriculum thinking } \\
\text { with focus on national } \\
\text { goals and measurable } \\
\text { outcomes (Taylorism) in } \\
\text { order to educate a com- } \\
\text { petent and employable } \\
\text { workforce. An example } \\
\text { is the National Curricu- } \\
\text { lum in the UK. }\end{array}$ & $\begin{array}{l}\text { Focus on detailed na- } \\
\text { tional performance } \\
\text { standards and on com- } \\
\text { petition (scientific man- } \\
\text { agement theories). }\end{array}$ \\
\hline 3 & $\begin{array}{l}\text { The democratic aim and } \\
\text { approach left many cur- } \\
\text { riculum decisions to } \\
\text { professional leaders and } \\
\text { teachers in collaboration } \\
\text { with students and par- } \\
\text { ents. } \\
\text { Leader-teacher relations } \\
\text { built on trust and profes- } \\
\text { sional expertise. }\end{array}$ & $\begin{array}{l}\text { This scientific curricu- } \\
\text { lum thinking leaves little } \\
\text { room for professional } \\
\text { leaders and teacher in- } \\
\text { terpretation, discretion. } \\
\text { Leader-teacher relations } \\
\text { built on monitoring and } \\
\text { standards/manuals. }\end{array}$ & $\begin{array}{l}\text { Strong leadership (prin- } \\
\text { cipal-agent theories: top- } \\
\text { down setting of direc- } \\
\text { tion and accountability). }\end{array}$ \\
\hline 4 & $\begin{array}{l}\text { A comprehensive, non- } \\
\text { streamed school was } \\
\text { constructed. }\end{array}$ & $\begin{array}{l}\text { Segregated school sys- } \\
\text { tems are common, both } \\
\text { public and private. }\end{array}$ & $\begin{array}{l}\text { Free choice of services } \\
\text { (rational choice theories: } \\
\text { rational thinking, maxi- } \\
\text { mising personal gains). }\end{array}$ \\
\hline
\end{tabular}

History shows that UK/US education was well-prepared for the contemporary forms of accountability promoted by transnational agencies. The Nordic systems were not that well-prepared. Not only did new transnationally inspired expectations meet the social capital outlined above: the traditions, structures, norms and values of the education systems and its practitioners. They also met decades-old structures in public governance. They can be found in educational legislation, in legal staff regulation and in the ways working conditions and wages are regulated or negotiated.

\section{NEO-LIBERAL GLOBALIZATION}

Since World War II we have seen a strong tendency towards a Global market place: The free flow of goods, services, education, people, workers, finances and information 
has been a major effort in economy and politics. This has carried a tendency to include more and maybe all spheres of societies into a market-place logic. This is also the case in public management, where neo-liberal New Public Management is being constructed as an overarching set of principles that are being played out in very different ways in different countries. Two core principles are always present: marketization and managerialism are interdependent and represent very strong trends being imposed on most of the world since World War 2 through the initiatives of the World Bank, the International Monetary Fond, and trans-national agencies like the OECD and the EU Commission (Moos, 2009b). Marketization means the core values are being made effective: e.g. decentralisation, consumers' choice, competition, outcomes, effectiveness, efficiency and comparisons (Moos, 2012a).

Governance presupposes agencies of management but also requires, and gains, the cooperation of the subjects involved. According to Foucault (1991) this is the defining characteristic of every modern society. Governance derives its legitimacy not from a legal-rational authority but from the rationale of market efficiency.

The neo-liberal technologies of governance (Dean, 1999; Peters et al., 2000) as well as education rely heavily on the market as the basis for, and logic of public management. They are founded on the devolution of management from the state to local levels, to local institutions (in the case of education to self-managing schools) to classrooms (classroom management techniques) and to individual level (self-managing students).

The concept of human beings is transformed from a notion of autonomous citizens into choosers or consumers of services. So, translated into the school context, parents, and their children, 'consume' 'educational services' through the exercise of choice. 'Freedom of choice' is the overriding good as opposed to active involvement as members of a community discussing and influencing decision-making. This logic - more market less state - then regulates every sphere of life.

The second core accountability of NPM is managerial: as citizens as consumers demand to know what the state and its agencies spend tax-money for and as many decisions are decentralised from state to local authorities and further on to institutions the state needed to develop new ways of enacting accountability. It thus invented - or took over from trans-national agencies - and implemented a wide range of managerial technologies like very detailed goals, standards and indicators, documentations, quality control instruments and testing.

As mentioned this accountability trend has very often brought specific ways of teaching, teaching to the test. Because schools and teachers want to survive as institutions and also to give their students what is seen as the best of foundations for advancing in education and life, the best exam results, they want to ensure that student perform their best in exams and tests (Nicholes \& Berliner, 2007).

In short: Global and transnational influences that are very similar in their basic thinking. National responses are similar, but not identical. The basic logics of globalisation are, the logics of the neo-liberal marketplace: strong market and weak state, consumer choice, competition and therefore comparison, strong leadership and focus on output with accountabilities. It builds mainly on principal-agent theories (basic assumption: the principal delegates work to an agent and uses, preferably, economic incitements), rational choice theories (basic assumption: people act rationally in order to maximise 
their self-interest), transaction cost theories (basic assumption: the state must cover some of the cost generated through transactions on the marketplace), and scientific management (Taylorism: workflows can be split into small fractions and analysed in order to standardise the work of each operation).

\section{FROM WELFARE STATES TO COMPETITIVE STATES}

Economy frames the contemporary state (Moos, 2012b). This has crucial influences on public sector governance and thus on education and educational leadership. Denmark and many other Western states have developed from welfare states primarily to competitive states over the past 30-40 years (Pedersen, 2010).

In the post-war years we have seen the emergence of welfare states, where areas of civil society were taken over by the state that would protect its citizens and thus further social justice, political equity and economic equality. Full employment was a main goal, and the public sector was seen primarily as serving citizens. E.g. citizens were supported in case of unemployment.

Transnational agencies were driving forces behind the opening of national economies towards a global competition from the 1970s and onwards, picking up more speed from the mid-1990s. Economic aims shifted from growth through full employment and increased productivity (of the labour force and technology) towards growth through international trade and investment. National governments increasingly worked through their memberships in international organisations on the regional markets.

In the 1970s governments began to turn national economies in a neo-liberal direction that built on rational choice, increasing market influence and minimal state influence (e.g. deregulation, privatisation, outsourcing). Citizens were seen more as members of the labour force, with full responsibility for their own situation, and as consumers, and the public sector was seen primarily as a service organ for production and trade in the national, innovative system. The state influences the availability and competencies of the labour force and of the available capital. The competitive state is characterised (Pedersen 2010, 72) by being regulating by displaying best practices and budgets, by framing the availability of the labour force, capital and raw material, and by being an active state, encouraging individual citizens to enter the labour market.

\section{AN EXAMPLE: DANISH GOVERNANCE AND MANAGEMENT OF PUBLIC SECTORS}

There is a long tradition for negotiation in the Danish political system. Most governments have been minority governments, forcing government parties to find majorities for their legislation through negotiation with opposition parties; most economic politics have been negotiated between the market and the political establishment, so there is a tradition for having neither a market-driven nor a state-driven economy, but a mixed, negotiated economy (Pedersen 2010).

This trend seems to be in line with the soft governance politics, the open method of coordination, the EU introduced in 2000 (EC, 2000). Pedersen describes decision-making processes as play processes in three phases: (1) language play: focus on making sense 
and defining the problem at hand; (2) negotiating play: forming coalitions and agreeing on the frames; and (3) negotiation: reaching an agreement by majority (Pedersen 2010, 145). The focus on working with the open method of coordination is on construction of premises for decision-making and negotiation towards reaching agreement.

The public sector, which in the competitive state is seen as a service to the market, is governed by variations of what is often called New Public Management (NPM). This form of governance builds on a principal (politicians) agent (civil servants) (PA) ideology at several levels (state, municipality, institution), where enticements are developed in order to engage and encourage civil servants to work effectively and efficiently, while evaluations and quality assurances are meant to monitor and assess the outcomes (Tyler, 1949). An important move has been to decentralise decisions from state to local levels, thus leaving institutions with the autonomy to lead the ways work is carried out within national aims and frames. This structure has created new institutions, which need to be responsive to the surroundings and the consumers and thus need to have room for leadership. Both institutions and leaders are subject to fluidity; aims and frames are subject to political negotiations and thus require institutions and leaders who can manoeuvre in a fluid, negotiable environment.

While there appears to be more room for manoeuvre for leaders of public institutions like schools, it does not mean that they are free to do whatever they feel like; national aims and frames are there and they are more detailed today than before. The social technologies used by the competitive state constitute strong guides. Taking part in the global economic competition also means taking part in a global educational competition. The Danish government states in the work programme from 2010, Denmark 2020 ([Government], 2010), that in relation to education their goals are: Danish students must be among the most competent in the world, and at least one university should be among the ten best European universities. The prime minister said that Danish students should be placed within the top five nations in PISA. The rating of education systems, schools and students is made so much easier by the international comparison programmes we participate in: PISA, PIRLS and TIMMS.

\section{ACCOUNTABILITY AND/OR INNOVATION IN EDUCATIONAL SYSTEMS?}

Neo-liberal policy makers are caught in an ironic squeeze in the global competition: On the one hand they want to measure educational systems by their position in international comparisons/rankings (e.g.: the PISA: Programme for International Student Assessment). On the other hand they know that societies, economics and therefore also education need to be creative and innovative in order to positions themselves in the competition for market shares (Geoghegan-Quinn, 2011).

Multiple analysis have shown how testing - and especially high-stakes testing - is changing the ways educational systems, schools and teachers conceive and practice teaching (Education, 1958; Hopman, 2008; Moos, 2009b): Tests can make teachers think and act more narrowly or distort curriculum, so content matters are being vulgarized and the focus is being on facts and instrumental skills and not on problem based learning and creativity. Political statement on the need for going back to basics, like reading and writing skills, underscores a tendency to 'teach for the test' because 
teachers want to support their students in line with official expectations and they also want to score high on the national league tables. When the core emphasis in schooling is being moved from the learning processes to the outcomes of learning as measures in tests and the like, there is a risk that teachers will adapt their teaching to the ways the tests are constructed. As most standardized tests are testing skills and active knowledge that can be reproduced on command, there is a tendency to 'hand over' the information to students, leaving little room and time for 'creativity': curiosity, testing ideas in practice, experimenting, self reflection. Creativity can be defined as a combination of cognitive-social processes and personal competences, defined as the ability to think outside the box and conceive new ideas, methods, materials, products and actions (Education, 1975).

Closely related to the concept of creativity is the concept of 'innovation:' a social process, where risks and possibilities are identified and creativity is being used to find new solutions or products. This concept is more often connected to industries and labour: How to develop products and services to an ever-changing market. An overarching concept is the 'entrepreneurship' that is sometimes understood as the competence to learn how to start up a new enterprise and sometimes as the competencies to be flexible and creative when meeting and handling social and economical changes (Education, 1975).

The basis for creativity is a criticism of the existing state of affairs (Andersen et al., 2007). In schools one can see that culturally diverse environments leave more space for creativity, if they build on respect for the other cultures. Education should also be based on practical and experimental pedagogic with room for experiments, for mistakes, for criticism, for reflections; deliberation and collaboration. Innovation involves creation of new knowledge or new combinations of old insights. They come out of interaction between people with diverse talents, interests, insights and experiences in open communication: generalized trust and participatory democracy contribute to creativity.

\section{DELIBERATIVE DEMOCRACY}

Communicative competencies are pivotal for students as well as citizens of contemporary societies: those are the competencies needed for influencing the construction of premises for decision-making. Community members need to be able to negotiate their positions, their interests and also the meaning of what is going on, or what they think should be going on. Interpretation of impressions and experiences seem to be more important now than ever before because the number of information, data and impressions is so very high today. Very often it is impossible for individuals to make interpretations. They need to communicate and negotiate with peers and other people.

Some children are raised in families, where communication skills are developed on a daily basis because parents talk with their children and encourage them to speak up and make their arguments. This makes it easier for them to manage the conversations and dialogues in school and thus to prosper from the community of peers and teachers.

Unfortunately some children are not that privileged. Their families are not able to or willing to involve them into conversations or deliberations. They cannot provide an 
appropriate background for the upbringing to participate in democratic conversations and negotiations. So those children are underprivileged and not being brought up to living as independent adults.

Schools in democratic societies therefore have many responsibilities: Not only to support children to acquire basic skills and active knowledge as high stake accountability systems are focusing on, but also to support them in getting good communication competencies.

Experiences from school practices (Moos \& Kofod, 2011) show that teaching can be whole-class teaching with the many possibilities for teacher's control and student negotiations. In more contemporary teaching forms, like project work and group work, some of the couplings are loosened. The teachers still decide issue, but students or groups of students can choose the problem they want to investigate. The students also choose how to work, how to find solutions to their problems and how to present them to their peers. The teacher sets the practical frames and demands collaboration and product. Those forms are parallel to some of the forms used at the school and team level and therefore there is room for student negotiations in some phases of the work. The negotiations can develop their communicative competencies.

There can be a tradition for open relations between teachers and students in some schools. There can also be traditions for delivering a great deal of the instruction verbally: teachers often enter into dialogues, problem solving processes or discussions with students in class on the basis of circular questioning, thus giving room for student involvement and verbal communication. It is also a tradition that teachers involve students in decisions on what and how they should learn.

The teaching and learning forms are as important as the content matters, but these are not measured in the managerial accountability regimes.

\section{DECISION MAKING THROUGH NEGOTIATION}

When looking at decision-making as a communication process we can distinguish three phases: The first phase it the construction of premises. Here the stage, the frame and the agenda are set; the discourses are developed and the positions are taken. The next phase is the decision-making, and the third phase is the connecting phase where one is interested in evaluating the effects of the decisions: Are they accepted and implemented and what is going to happen, if they are not accepted? (Moos, 2009a; Moos, 2012b).

We can distinguish three general forms of influence: Direct influence, strategic influence and reciprocal influence. The reciprocal influence has many forms: Setting the agenda, sense making, as will be described later on, and constructing the premises for decision making, as described above. In the core of those forms is the deliberations and negotiations, the reciprocity of relations; they accept that agents are dependent on each other. They have more often than not diverse perspectives on education and professional work and diverse interests and values, but they need to find an appropriate and pragmatic level of consensus in order to proceed from one situation to the other from one day in the schools life to the next. This kind of influence is working in the everyday life and in the interactions and communications between agents. We heard 
principals talk about it and focus on it more frequently when we revisited the schools than when first we visited them. This is a sign that school leaders are getting out of their offices more and into staff rooms, classrooms and corridors.

The second form of influence is named strategic influence: Leaders of organizations have to produce strategic plans for one, two or three years. Here they evaluate the status and describe the goals, initiatives and direction for the period to come. In many places much work is being invested in this kind of planning only to see that the administrative and political premises for the plans are being changes every so often. The detailed aims and actions laid out in strategic plans are not met, but on the other hand they can serve important purposes by indicating a direction that everybody can use as a map that can help them make-sense of their situation (Weick, 2001). So the impact of the plan is more in the field of sense making than in the field of strict plans for the future.

Thirdly we can describe the direct influence (Barach \& Baratz, 1962). Here an agent makes the decision and communicates it to the followers to obey by. Principals in our study also use this kind of influence, but there is a clear tendency that they are trying to use the other kinds of influence more than the direct influence. Often they emphasis the first phase, the construction of premises, by involving teachers in making sense of the situations and the demands before decisions are made. In some cases - when schools are in challenging circumstances and firm actions are needed very fast, principals take the lead and make decisions. In other cases, where principals are new to the school and a shared sense of the culture and the values has not been established yet, principals also take the lead. When there are big disagreements between individuals or groups in the staff, or if the external expectations collide with teachers' professional identities or opinions, principals have to make decisions. There is a clear tendency that when the external standards, aims or demands for accountability are very tight - like in high-stake testing systems, then principals are using more direct power than in other systems, as shown in the analysis of the initial case stories (Moos et al., 2008).

We see a trend towards more reciprocal influence in schools. This is very much in line with the demand for negotiations in fluid environments and with the 'soft governance' trends. A powerful illustration of this position can be read in Karen Seashore Louis' quote:

'Many contemporary democratic theorists argue that the most essential element of democratic communities today is their ability to engage in civilized but semipermanent disagreement. Articulating a humanist voice that calls for respecting and listening to all positions - but then being able to move forward in the absence of consensus - will be the critical skill that school leaders need to develop when the environment makes consensus impossible." (Louis, 2003, p. 105)

The fluid institution and environment calls for 'semi-permanent disagreement' and 'respecting and listening to all positions' when moving forward. 


\section{DISCUSSION}

The two ways of looking at teaching call for different forms of leadership, different relations between school leaders and teachers. In the UK-US system there is a move towards prescribing teacher behaviour. The Nordic version contains more understanding of the need of teachers to have room for interpretation within general aims (Moos, 2013c).

Leading is the major task of school leaders in the sense of leading the way and being at the head of. Leadership is an interactive practice say Leithwood and Day (2007a, p. 4) They agree with Woods, when he writes, 'the essence of leadership is not the individual social actor but a relationship of almost imperceptible directions, movements and orientation having neither beginning nor end' (2005, p. 115). And Leithwood and Day continue: 'while reciprocity is fundamental to such relationships, the defining contribution to an organisation is an emergence of a shared sense of direction with perceptible influence, eventually, on teachers to move in that direction. Direction and influence are at the core of most conceptions of leadership' $(2007,4)$. Concerning the Nordic context one could add that leaders shall influence teachers, but they must leave room for interpretation (2007a).

Leaders, however, do not work in a vacuum; schools are built on relations with the outside world, and that means that school leaders are responsible for bringing external expectations into the school and implementing them by cultivating acceptance, by adjusting and adapting them to the internal sense of meaning of the school. There are many legitimate and legal expectations from stakeholders outside and inside schools that create, limit and direct the work. Many of these expectations contradict each other, and many external expectations, demands and structures can seem strange and meaningless to professional cultures. This puts the school leader in a position, where she/he needs to interpret, translate and mediate these external demands in order to facilitate sense-making and the creation of a shared direction inside the school.

This article has argued that schools need to handle contradictions and school leaders need to balance dilemmas between neo-liberal inspired demands for proficiencies in basic skills, as they are measured in international and national tests, and comprehensive demands for developing deeper competencies like curiosity and communication. Curiosity is the foundation for learning and creativity. Pupils and students are motivated for learning only through the curiosity-driven investigations and questioning of the facts and opportunities (Moos et al., 2013). This learning may be threatened by an educational system and school that only asks for, what is known on the forehand like in the multiple choice tests: the answer is given in the ticking options. Acquiring communication competences asks for room for listening, talking and practicing. Those competences can be developed and made use of in a community of practice (Wenger, 1999). Membership of communities both nurtures communicative competences and use them in the negotiations for membership: Students are accepted as members if the participate in negotiation the positions, borders and direction of the communities. This endeavour may be endangered if major part of teaching time is individualized.

Governments and local educational authorities make policies, plans, principles and strategies for education in school. Some of these are accompanied by social technologies (e.g. tests, manuals, standards) and some are declarations of intent: descriptions of 
aims or values. This can take the form of soft governance that leaves room for school discretion, interpretation and manoeuvre, when schools choose between particular ways and methods. The intention is of course to make schools develop according to the general aims and directions, as they are described in 'organisational ideas' (Røvik, 2007). Røvik describes the difficulty of implementing ideas into existing organisations in effective ways that change and form their practises and thinking. Therefore, he argues, much more attention needs to be given to the phase where the idea meets the organisation. The idea needs to be understood and accepted by the organisation, leaders and teachers, in order to have an effect on practice and thinking. Ideas need to be translated in order to fit the mental models or worldviews of professionals. In this aspect of school life leaders and leadership are key players. They receive the information and demands from the outside, but they also know the organisation, its culture and the professionals in it. They are better positioned than anyone else to translate, reformulate and negotiate the direction of what needs to be done, so that it makes sense to the teachers.

\section{REFERENCES}

Andersen, T. M., Holmström, B., Honkapohja, S., Korkman, S., Söderström, H. T., \& Vartiainen, J. (2007). The nordic model. Embracing globalization and sharing risks. Helsinki: Taloustieto Oy.

Barach, P., \& Baratz, M. S. (1962). The two faces of power. American Political Science Review, 56 (4), 947-952.

Blossing, U., Imsen, G., \& Moos, L. (2013). Progressive education and new governance in Denmark, Norway and Sweden. In U. Blossing, G. Imsen \& L. Moos (Eds.), The nordic education model: 'A school for all' encounters neo-Liberal Policy. Dordrecht: Springer.

Bobbitt, F. (1924). How to make a Curriculum. Boston: Houghton Mifflin.

Bourdieu, P. (1977). Outline of a theory of practice. Cambridge: Cambridge University Press.

Bourdieu, P. (1990). The logic of practice. Stanford: Stanford Univeristy Press.

Bourdieu, P., \& Passeron, J. C. (1977). Uddannelsessystemets ideologiske funktion [The ideological function of education]. In B. Berner, S. Callewaert \& H. Silberbrandt (Eds.), Skole, ideologi og samfund (pp. 42-69). København: Munksgaard.

Day, C., \& Leithwood, K. (2007a). Building and sustaining successful principalship: Key themes. In C. Day \& K. Leithwood (Eds.), Successful principal leadership in times of change (pp. 171-188). Dordrecht: Springer.

Day, C., \& Leithwood, K. (Eds.). (2007b). Successful principal leadership in times of change. Dordrecht: Springer.

Dean, M. (1999). Governmentality: power and rule in modern society. London: Sage.

Dewey, J. (1901). The situation as regards the course of study. Journal of Proceedings and Addresses of the Fortieth Annual Meeting of the National Education Association, 333-348.

Dewey, J. (1916). Democracy in education. New York: Macmillan.

European Council (2000). Presidency Conclusion. Lisbon, 23/24 March.

Education, M. o. (1958). Consolidation Act June 18th.

Education, M. o. (1975). Consolidation Act on the Folkeskole, June 26th. 
Eurydice (2012). Key Data on Education in Europe 2012. Brussels: European Commission. Evans, G. (1992). Is Britain a class-divided society? A re-analysis and extension of marshall et al.'s study of class consiousness. Sociology, 26 (2), 233-258.

Foucault, M. (1991). Governmentalité. In G. Burcell, C. Gordon \& P. Miller (Eds.), The foucault effect: Studies in governmentality (pp. 87-104). Hempel Hempstead: Harvester Wheatsheaf.

Geoghegan-Quinn, M. (2011). Horizon 2020. Retrieved from http://ec.europa.eu/ research/horizon2020/pdf/ proposals/communication_from_the_commission_-_ horizon_2020_-_the_framework_ programme _for_research_and_innovation. pdf\#view=fit\&pagemode=none

Government, R. (2010). Danmark 2020 [Denmark 2020]. Copenhagen: Regeringen.

Hopman, S. T. (2008). No child, no school, no state left behind: schooling in the age of accountability. Journal of Curriculum Studies, 40 (4), 417-456.

Louis, K. S. (2003). Democratic schools, democratic communities. Leadership and Policy in Schools, 2 (2), 93-108.

Moos, L. (2009a). A general context for new social technologies. Nordic Educational Research, 29 (1), 79-92.

Moos, L. (2009b). Hard and soft governance: the journey from transnational agencies to school leadership. European Educationa Research Journal, 8 (3), 397-406.

Moos, L. (2011). Sustaining leadership through self-renewing communication. In L. Moos, O. Johansson \& C. Day (Eds.), How school principals sustain success over time (pp. 127-150). Dordrecht: Springer.

Moos, L. (2012a). Democratic schooling: Between outcomes and deliberation. In J. Brown, H. Ross \& P. Munn (Eds.), Democratic citizenship in schools. Edinburgh: Dunedin.

Moos, L. (2012b). Educational leadership in a competitive state: a contradiction in terms? International Jouranl of Educational Management, 26 (5), 461-469.

Moos, L. (2013a). Postlude - wrap up of the argument. In L. Moos (Ed.), Transnational influences on values and practices in nordic educational leadership - Is there a nordic model? Dordrecht: Springer.

Moos, L. (2013b). Prelude - tuning the instrument. In L. Moos (Ed.), Transnational influences on values and practices in nordic educational leadership - Is there a nordic model? Dordrecht: Springer.

Moos, L. (Ed.) (2013c). Transnational influences on values and practices in nordic educational leadership - Is there a nordic model? Dordrecth: Springer.

Moos, L., Hansen, B., Bjørk, G., \& Johansson, O. (2013). Leadership for democracy. In L. Moos (Ed.), Transnational influences on values and practices in nordic educational leadership - Is there a nordic model? Dordrecht: Springer.

Moos, L., \& Kofod, K. (2011). Danish successful school leadership - Revisited. In L. Moos, O. Johansson \& C. Day (Eds.), How school principals sustain success over time. Dordrecht: Springer.

Moos, L., Kofod, K., \& Krejsler, J. (2008). Successful principals: Telling or selling? - On the importance of context for school leadership International Journal of Leadership in Education, 11 (4), 341-352.

Nicholes, S. L., \& Berliner, D. C. (2007). Collateral damage. How high-stkes testing corrupts America's schools. Cambridge MA: Harvard Education Press. 
Pedersen, O. K. (2010). Konkurrencestaten [The competitive state]. Copenhagen: Hans Reitzels Forlag.

Peters, M., Marshall, J., \& Fitzsimons, P. (2000). Managerialism and educational policy in a global context: Foucault, neoliberalism and the doctrin of self-management. In N. C. Burbules \& C. A. Torres (Eds.), Globalization and education: critical perspectives (pp. 109-132). New York: Routledge.

Røvik, K. A. (2007). Trender og translasjoner. Ideer som former det 21. århundrets organisasjon [Trends and translations. Ideas that form the 21. Century organisations]. Oslo: Universitetsforlaget.

Taylor, F. W. (1911). Principles of scentific management. New York: Harper \& Brothers.

Tyler, R. W. (1949). Basic principles of currículum and instruction. Chicago: University of Chicago Press.

Wenger, E. (1999). Communities of practice. Learning, meaning and identity. Cambridge: Cambridge University Press.

Wilkinson, R., \& Pickett, K. (2009). The spirit level. Why more equal societies almost always do better. London: Penguin Books.

Woods, P. A. (2005). Democratic leadership in education. London: Paul Chapman.

Fecha de recepción: 10 de julio de 2012.

Fecha de revisión: 10 de julio de 2012.

Fecha de aceptación: 11 de octubre de 2012. 
